\title{
A Study of the Sensitivity and Specificity of the Magnetic Resonance Imaging (MRI) Technique used in the Diagnosis of Endometriosis versus the Intraoperative Appearance Considered the Reference Standard in the Diagnosis of Endometriosis
}

Alexandra RADU ${ }^{1,2,3}$, Elvira BRATILA ${ }^{1,2}$

\begin{abstract}
Endometriosis is a gynecological pathology with chronic symptoms, which negatively affects the patient's quality of life 1 . The prevalence of endometriosis in asymptomatic women is between $2 \%$ and $50 \%$, depending on the populations studied and the method of diagnosis. The severity of the symptoms as well as the probability of diagnosing endometriosis increases with age9. Because endometriosis is a gynecological condition with a nonspecific clinical picture, sometimes even asymptomatic, imaging technology can be considered the first line of diagnosis for this pathology. The main objective of this study is to evaluate the sensitivity and specificity of nuclear magnetic resonance imaging (MRI) used in the diagnosis of endometriotic lesions depending on their location, and compare the results obtained with the intraoperative appearance considered a reference standard in the diagnosis of endometriosis. Our study revealed the highest specificity for MRI in the case of endometriotic bladder invasion, respectively the highest sensitivity for endometriotic rectal nodules.
\end{abstract}

Keywords: endometriosis, MRI, sensitivity, specificity, intraoperative.

\section{Rezumat}

Endometrioza reprezintă o patologie ginecologică cu simptomatologie cronică, care afectează în mod negativ calitatea vieții pacientelor1. Prevalența endometriozei la femeile asimptomatice este cuprinsă între $2 \%$ si $50 \%$, în funcție de populațiile studiate, precum și de metodele de diagnostic utilizate. Severitatea simptomelor precum și probabilitatea diagnosticării endometriozei crește odată cu vârsta9. Fiindcă endometrioza reprezintă o afecțiune ginecologică cu un tablou clinic nespecific, câteodată chiar asimptomatică, tehnologia imagistică poate fi considerată prima linie de diagnostic pentru această patologie. Obiectivul principal al prezentului studiu este evaluarea sensibilității și specificității tehnicii imagistice prin rezonanță magnetică nucleară (RMN) utilizată în diagnosticul leziunilor endometriozice în funcție de localizarea acestora, precum și compararea rezultatelor obținute cu aspectul intraoperator considerat standardul de referintă în diagnosticul endometriozei. Studiul nostru a relevat cea mai mare specificitate pentru RMN în cazul invaziei endometriozice a vezicii urinare, respectiv cea mai mare sensibilitate pentru nodulii rectali endometriozici.

Cuvinte cheie: endometrioză, RMN, sensibilitate, specificitate, intraoperator.

${ }^{1}$ "Prof. Dr. Panait Sarbu" Clinical Hospital of Obstetrics and Gynecology, Bucharest, Romania

${ }_{\text {" }}$ Carol Davila" University of Medicine and Pharmacy, Bucharest, Romania

3 Doctoral School of "Carol Davila" University of Medicine and

Pharmacy, Bucharest, Romania
Corresponding author:

Alexandra RADU, „Prof. Dr. Panait Sarbu” Clinical Hospital of Obstetrics and Gynecology, Bucharest, Romania.

E-mail: alexandra.bruja@drd.umfcd.ro 


\section{INTRODUCTION}

Endometriosis is a gynecological disease first identified in 1860, following the microscopic findings of the Austrian pathologist Karl von Rokitansky, characterized by the presence of endometrial stroma and dysfunctional glands of the endometrial type, often accompanied by reactive fibrosis and muscle metaplasia outside the cavity ${ }^{1,2}$.

This definition of endometriotic disease is a limited and inefficient anatomical definition in describing the natural history of endometriosis, the complexity of its clinical picture, it's frequent recurrence, the basic molecular pathophysiology or even its ability to react to currently available management methods $\mathrm{s}^{2,3,4,5,6}$.

Lately, the definition of endometriosis has evolved, focusing more on the patient, the natural history of the disease from adolescence to menopause, the variety of tissues involved, it's complex, chronic and systemic nature, but also the need for treatments that have as a long-term ovulation suppression effect ${ }^{2,4,7}$.

Progress in the last two decades shows that endometriosis is a complex clinical syndrome characterized by a chronic estrogen-dependent inflammatory process that mainly affects the pelvic organs ${ }^{2}$. The multifactorial etiology, along with its high prevalence, make it extremely similar to various other inflammatory diseases such as inflammatory bowel disease or gastroesophageal reflux disease ${ }^{2,3,4}$. However, the uniqueness of the disease comes precisely from its addiction on the hormone estrogen considered as the biological trigger for the inflammatory process ${ }^{2}$.

\section{BACKGROUND AND AIMS}

Endometriosis is a worldwide gynecological disease that primarily affects women of reproductive age. To a lesser extent, endometriosis is also found in adolescents or menopausal women ${ }^{8}$.

Given the non-specific symptoms of this gynecological disease, it is often the case that the diagnosis of endometriosis is overlooked by medical staff.

However, when the patient describes localized pelvic pain with a cyclical character, the anamnesis becomes an essential tool in the diagnosis of endometriotic disease. Although there are situations in which the clinical examination of patients with endometriosis is devoid of pathological changes, often the pelvic examination reveals either a "frozen" retroverted uterus or palpable nodules located in the posterior fornix of the vagina ${ }^{10}$.
Although there are a multitude of diagnostic imaging possibilities, they also have a different sensitivity and specificity depending on the location of endometriotic lesions.

Therefore, in order to obtain a diagnosis, the anamnesis and the clinical examination are completed with the use of imaging investigations. Transvaginal ultrasound (TVU) is considered the first-line imaging method in the examination of patients with suspected endometriosis ${ }^{11,12}$. Additionally, the use of MRI increases the accuracy of the diagnosis of endometriotic disease. In most cases, the clinical signs identified on physical examination require additional MRI examination with adequate intestinal preparation ${ }^{13}$.

Starting from the premises mentioned above in the text, it results that endometriosis is a current public health problem and a pathology of interest to specialists in the field, and the study of sensitivity and specificity of MRI technique used in the diagnosis of endometriosis can have a positive impact on the monitoring management of patients suspected of endometriosis.

The general objectives of the study are: to assess the sensitivity and specificity of the MRI technique used to diagnose endometriotic lesions, depending on their location in the three pelvic compartments, as follows: anterior pelvic compartment represented by the bladder, middle pelvic compartment represented by the utero-sacral ligaments and the cardinal ligaments and the posterior pelvic compartment represented by the recto-vaginal septum and intestinal nodules. Endometriotic lesions located at the level of parameters were further investigated. Also, another objective of the study is to compare the results obtained after MRI examination of patients with endometriosis, with the results obtained after surgery for endometriosis.

\section{PATIENTS AND METHODS}

\section{Study Design}

The present study is a prospective, observational study, which included a total of 144 patients with endometriosis, of which only 99 patients were eligible according to the selection criteria for the purpose of the proposed study. It took place over a period of two years, between October 2018 and December 2020, in three specialized medical centers represented by: „Prof. Dr. Panait Sarbu" Clinical Hospital of Obstetrics and Gynecology Bucharest, Monza Hospital Bucharest and „Euroclinic - Regina Maria” Hospital Bucharest. 
The prospective study required the development of a protocol for imaging examination of patients, depending on the clinical suspicion of the location of endometriotic lesions.

Both the research methodology and the informed consent of the patients included in the study were approved by the Ethics Commissions of the three specialized medical centers mentioned above.

The inclusion and exclusion criteria for the study population and the study research methodology were summarized as follows:

Inclusion criteria for the study group:

- clinical picture suggestive for endometriosis;

- MRI examination highly suggestive for endometriosis;

- informed consent signed for MRI examination to include patients in the study;

- informed consent signed for the surgical therapeutic conduct of endometriosis at the inclusion of $\mathrm{pa}^{-}$ tients in the study;

- informed consent signed for taking intraoperative histopathological samples to include patients in the study.

Exclusion criteria for the study group:

- failure to give the informed consent signed for the MRI examination;

- failure to give the informed consent signed for the surgical therapeutic conduct of endometriosis.

\section{Patients}

All of the patients selected to be part of this study underwent imaging examination using a 3 Tesla nuclear magnetic resonance system and surgical treatment consisting of resection of endometriotic lesions. The final diagnosis of endometriosis was confirmed by histopathological examination. MRI examinations were performed by radiologists competent in MRI and involved a preparation and examination protocol specific to endometriosis. The MRI investigation was scheduled starting with the 8th day of the menstrual cycle, the oral feeding was stopped 4-6 hours before the examination, the patients were examined with the bladder in semi-replenishment and the digestive tract was prepared by administering an enema with $2-3$ hours before the imaging investigation. For a better visualization of the vagina and rectum, distension media (ultrasound gel) were used. The evaluation included MRI images using T2 and T1 weighted multiplanar sequences.
At least two orthogonal planes were used for the T2-weighted MRI sequences. Two bidimensional weighted T2 MRI sequences (sagittal, axial, oblique) were used to evaluate deep endometriosis. For the systematic visualization of the kidneys and the abdominal cavity (cecum, appendix, small intestines, large intestines) the T2-weighted axial two-dimensional MRI sequences were used.

The MRI examination reports included a detailed description of the endometriotic lesions including the size of the lesions, as well as the anatomical location of the endometriotic lesions visible on examination.

\section{Statistical analysis}

Statistical analysis was performed using IBM SPSS Statistics 25 and Microsoft Office Excel / Word 2013. Quantitative variables were tested for distribution using the Shapiro-Wilk test and were expressed as means with standard deviations or medians with inter-percentile intervals. Categorical variables were expressed in absolute or percentage form and were tested using Fisher's Exact Test. The existing correlations were made using the Pearson and Spearman's rho correlation coefficient depending on the distribution of quantitative variables.

\section{RESULTS}

\section{Baseline characteristics of the study population}

For the 99 patients with endometriosis included in the study, the following variables obtained from the anamnesis and clinical and paraclinical examinations were studied: clinical appearance, anti-mullerian hormone $(\mathrm{AMH})$ value prior to surgery, American Fertility Society (AFS) score, MRI examinations, but also postoperative complication rate as suggested in Table 1.

Table 1. Baseline characteristics of the study population

\begin{tabular}{|c|c|}
\hline Parameter & Value \\
\hline \multicolumn{2}{|c|}{ Clinical examination appearance (No.,(\%)) } \\
\hline Modified & $83(83.8 \%)$ \\
\hline Normal & $10(10.1 \%)$ \\
\hline Inconclusive & $6(6.1 \%)$ \\
\hline MRI & $99(100 \%)$ \\
\hline $\begin{array}{l}\text { AMH prior to surgery } \\
\quad \text { (average } \pm \text { SD) }\end{array}$ & $1.803 \pm 2.833$ \\
\hline $\begin{array}{l}\text { AFS-R total Score } \\
\text { (average } \pm \text { SD) }\end{array}$ & $3.46 \pm 0.747$ \\
\hline Postoperative complications (No.,(\%)) & $1(1.0 \%)$ \\
\hline
\end{tabular}




\section{MRI examination of the study group}

Following the MRI investigation of the patients included in the study, the following aspects were found, also presented in Table 2. Among the patients included in the study, $29.6 \%$ had parametrial endometriotic lesions, more frequently bilateral (11.2\%); $27.1 \%$ of patients had lesions of the recto-vaginal septum; $44.9 \%$ of patients had utero-sacral ligament (USL) lesions, more frequently bilateral (27.6\%); $29.6 \%$ of patients had endometriotic nodules of the rectum, more frequently unique $(28.6 \%) ; 13.4 \%$ of patients had sigmoid endometriotic nodules more frequently unique (11.3\%); $2 \%$ of patients had ileal endometriotic nodules; $14.3 \%$ of patients had bladder invasion; $67.3 \%$ of patients had other locations of endometriosis; The mean size of the endometriotic nodules of the rectum was $21.86 \pm 8.883$ $\mathrm{mm}$, with a median of $20 \mathrm{~mm}$; The mean size of the endometriotic sigmoid nodules was $27.23 \pm 8.974 \mathrm{~mm}$, with a median of $27 \mathrm{~mm}$; the mean distance of intestinal lesions from the external anal sphincter (EAS) is $123.4 \pm 17.75 \mathrm{~mm}$, with a median of $120 \mathrm{~mm}$.

\section{The intraoperative appearance of the studied population group}

The intraoperative appearance of the patients included in the study revealed the following aspects described in Table 3.
Table 2. Description of endometriotic lesions observed on MRI

\begin{tabular}{|c|c|}
\hline \multicolumn{2}{|c|}{ Endometriotic lesions - MRI (No., (\%)) } \\
\hline \multicolumn{2}{|c|}{ Parametrial endometriosis } \\
\hline Right & $9(9.2 \%)$ \\
\hline Left & $9(9.2 \%)$ \\
\hline Bilateral & $11(11.2 \%)$ \\
\hline Recto-vaginal septum endometriosis & $26(27.1 \%)$ \\
\hline \multicolumn{2}{|c|}{ USL endometriotic lesions } \\
\hline Right & $14(14.3 \%)$ \\
\hline Left & $3(3.1 \%)$ \\
\hline Bilateral & $27(27.6 \%)$ \\
\hline Endometriotic nodules of the rectum & $\begin{array}{c}28(28.6 \%) \text { - unique, } 1(1 \%)- \\
\text { multiple }\end{array}$ \\
\hline Sigmoid endometriotic nodules & $\begin{array}{c}11(11.3 \%) \text { - unique, } 2(2.1 \%)- \\
\text { multiple }\end{array}$ \\
\hline Ileal endometriotic nodules & $2(2 \%)$ \\
\hline Bladder invasion of endometriosis & $14(14.3 \%)$ \\
\hline Other endometriotic implants & $66(67.3 \%)$ \\
\hline \multicolumn{2}{|c|}{ Lesion size - MRI (average \pm SD) } \\
\hline $\begin{array}{l}\text { Endometriotic nodules of rectum } \\
\text { ( } \mathrm{mm})\end{array}$ & $21.86 \pm 8.883$ \\
\hline Sigmoid endometriotic nodules ( $\mathrm{mm}$ ) & $27.23 \pm 8.974$ \\
\hline $\begin{array}{c}\text { Distance of intestinal lesions from } \\
\text { EAS (mm) }\end{array}$ & $123.4 \pm 17.75$ \\
\hline
\end{tabular}

Table 3. Description of the intraoperative findings

\begin{tabular}{|c|c|c|c|c|c|}
\hline Uterus appearance & $\begin{array}{l}\text { Anterior cul-de-sac- } \\
\text { appearance }\end{array}$ & $\begin{array}{c}\text { Right parametrium - } \\
\text { Enzian Score }\end{array}$ & $\begin{array}{c}\text { Right parame- } \\
\text { trium-appearance }\end{array}$ & $\begin{array}{c}\text { Left parametrium- } \\
\text { Enzian Score }\end{array}$ & $\begin{array}{c}\text { Left parame- } \\
\text { trium-appearance }\end{array}$ \\
\hline $\begin{array}{c}65(65.7 \%) \\
\text { Normal }\end{array}$ & $\begin{array}{c}7(7.1 \%) \\
\text { Red }\end{array}$ & $\begin{array}{c}11(11.1 \%) \\
\mathrm{B} 1\end{array}$ & $\begin{array}{c}1(1 \%) \\
\text { Red }\end{array}$ & $\begin{array}{c}11(11.1 \%) \\
\mathrm{B} 1\end{array}$ & 4 (4\%) Red \\
\hline $\begin{array}{l}15(15.2 \%) \\
\text { Fibroid }\end{array}$ & $\begin{array}{l}1(1 \%) \\
\text { White }\end{array}$ & $\begin{array}{l}24(24.2 \%) \\
\text { B2 }\end{array}$ & $\begin{array}{l}3(3 \%) \\
\text { White }\end{array}$ & $\begin{array}{l}28(28.3 \%) \\
\text { B2 }\end{array}$ & $3(3 \%)$ White \\
\hline $\begin{array}{c}19(19.2 \%) \\
\text { Adenomyosis }\end{array}$ & $\begin{array}{c}50(50.5 \%) \\
\text { Black }\end{array}$ & $\begin{array}{c}6(6.1 \%) \\
\text { B3 }\end{array}$ & $\begin{array}{c}37(37.4 \%) \\
\text { Black }\end{array}$ & $\begin{array}{c}12(12.1 \%) \\
\text { B3 }\end{array}$ & $\begin{array}{c}44(44.4 \%) \\
\text { Black }\end{array}$ \\
\hline $\begin{array}{c}\text { Recto-vaginal septum- } \\
\text { Enzian Score } \\
\end{array}$ & $\begin{array}{c}\text { Right USL-appea- } \\
\text { rance }\end{array}$ & Light USL appearance & $\begin{array}{c}\text { Intestinal lesions - En- } \\
\text { zian Score } \\
\end{array}$ & Rectum lesions & Sigmoid lesions \\
\hline 5 (5.1\%) A1 & $2(2 \%) \operatorname{Red}$ & $5(5.1 \%) \operatorname{Red}$ & $11(11.1 \%) \mathrm{C} 1$ & $33(33.3 \%)$ Unique & $15(15.2 \%)$ Unique \\
\hline $\begin{array}{l}11(11.1 \%) \\
\mathrm{A} 2\end{array}$ & $\begin{array}{l}4(4 \%) \\
\text { White }\end{array}$ & $1(1 \%)$ White & $17(17.2 \%) \mathrm{C} 2$ & 3 (3\%) Multiple & $4(4 \%)$ Multiple \\
\hline $\begin{array}{c}5(5.1 \%) \\
\text { A3 } \\
\end{array}$ & 18 (18.2\%) Black & $20(20.2 \%)$ Black & $22(22.2 \%) \mathrm{C} 3$ & & \\
\hline Ileum lesions & Bladder Invasion & Diaphragmatic lesions & Appendicular lesions & & \\
\hline $3(3 \%)$ & $21(21.2 \%)$ & $1(1 \%)$ & $1(1 \%)$ & & \\
\hline
\end{tabular}




\begin{tabular}{|c|c|}
\hline \multicolumn{2}{|c|}{ Lesion Size - Intraoperative findings $($ average \pm SD) $(\mathbf{m m})$} \\
\hline Anterior cul-de-sac & $25.18 \pm 6.746$ \\
\hline Right USL & $14.32 \pm 6.611$ \\
\hline Left USL & $14.0 \pm 7.532$ \\
\hline Rectum & $22.61 \pm 8.771$ \\
\hline Sigmoid & $25.1 \pm 8.704$ \\
\hline Ileum & $16.67 \pm 5.774$ \\
\hline
\end{tabular}

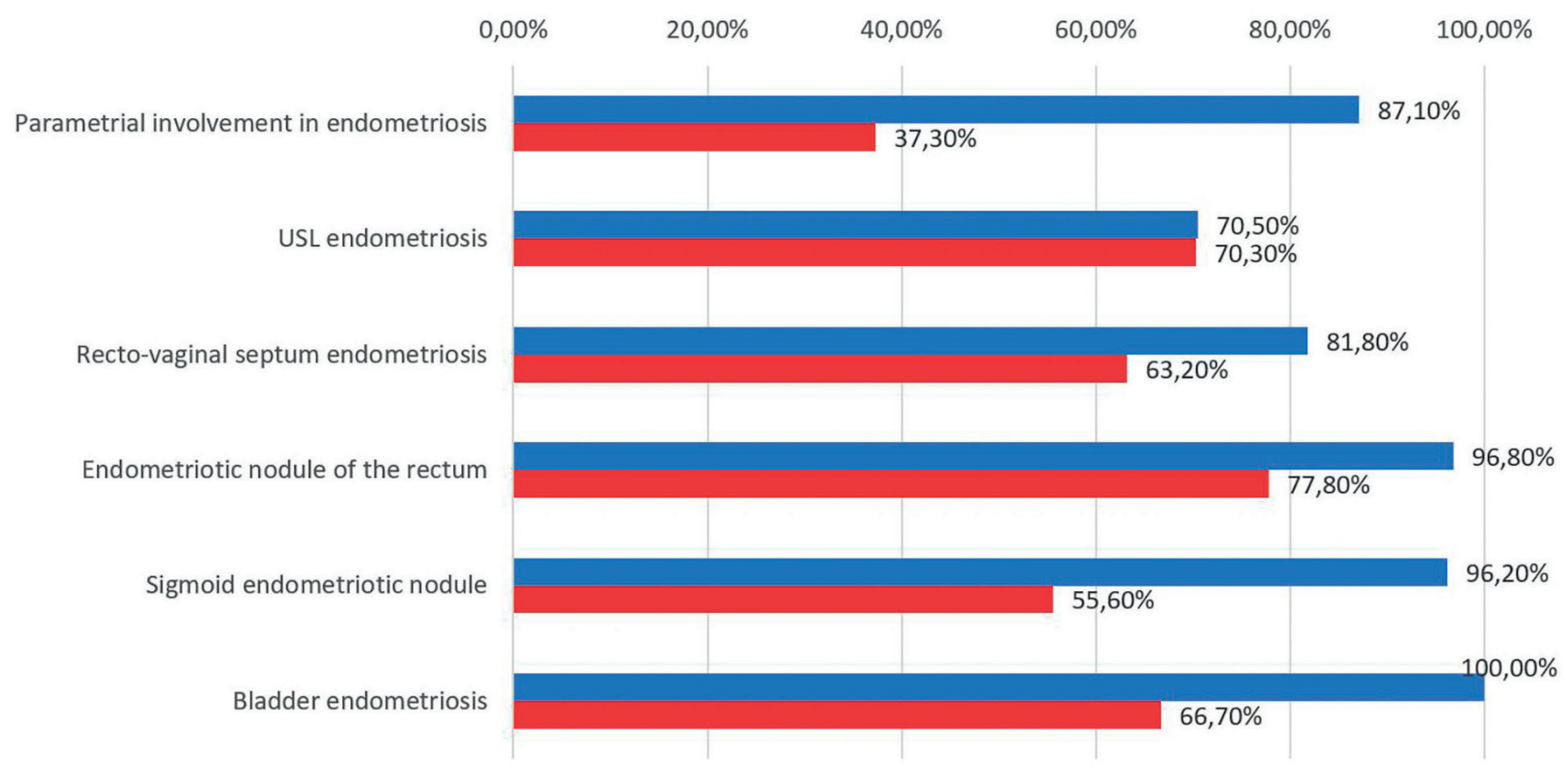

- Specificity $\square$ Sensibility

Figure 1. Sensitivity and specificity of MRI diagnoses in relation to the pathologies investigated

The data in the Figure 1 represent the comparison of MRI and intraoperative diagnoses for endometriosis. Associations of MRI diagnoses versus intraoperative appearance are statistically significant, according to Fisher tests $(\mathrm{p}<0.05)$. The results are described in Table 4, as follows:

Table 4. Sensitivity and Specificity of MRI in relation to the endometriotic lesions

\begin{tabular}{|l|c|c|}
\hline Type of endometriotic lesion & $\begin{array}{c}\text { Sensitivity } \\
\text { of the MRI }\end{array}$ & $\begin{array}{c}\text { Specificity } \\
\text { of the MRI }\end{array}$ \\
\hline Parametrial endometriotic lesion & $\mathbf{3 7 . 3 \%}$ & $\mathbf{8 7 . 1 \%}$ \\
\hline USL endometriotic lesion & $\mathbf{7 0 . 3 \% ;}$ & $\mathbf{7 0 . 5 \%}$ \\
\hline Recto-vaginal septum endometriotic lesion & $\mathbf{6 3 . 2 \%} ;$ & $\mathbf{8 1 . 8 \%}$ \\
\hline Endometriotic nodules of the rectum & $\mathbf{7 7 . 8 \%}$ & $\mathbf{9 6 . 8 \%}$ \\
\hline Endometriotic sigmoid nodule & $\mathbf{5 5 . 6 \%}$ & $\mathbf{9 6 . 2 \%}$ \\
\hline Endometriotic bladder invasion & $\mathbf{6 6 . 7 \%}$ & $\mathbf{1 0 0 \%}$ \\
\hline
\end{tabular}

Our study also revealed that the dimensions of the rectal nodules had a non-parametric distribution ( $p$ $<0.05)$ and the dimensions of the sigmoid nodules had a normal distribution ( $p>0.05$ ) according to the Shapiro-Wilk test, the correlation between the dimensions of the observed rectal nodules on MRI vs. Intraoperative appearance it is significant and of high degree ( $\mathrm{p}$ $=0.001, \mathrm{R}=0.599$ ) and the correlation between the dimensions of the sigmoid nodules observed on MRI vs. Intraoperative appearance, it is significant and of a very high degree $(p=0.005, R=0.809)$, the similarity between the dimensions being much higher. 


\section{DISCUSSION}

In a recently published meta-analysis, the sensitivity and specificity of MRI for the diagnosis of endometriosis of the recto-vaginal septum were $82 \%$ and $77 \%{ }^{14,16}$. However, in the case of our study, we found a sensitivity of $63.2 \%$ and a specificity of $81.8 \%$ for the diagnosis of endometriosis of the recto-vaginal septum on MRI.

On MRI, normal USL are usually not visible ${ }^{14,17}$ or are described as thin, regular, hypointense semicircular cords that run from the sides of the cervix and vaginal vault and have a dorsocranial path to the sacrum ${ }^{18}$.

USL endometriosis is described as nodularity in the ligament or as unilateral or bilateral hypotensive thickening of the ligament, with regular or irregular edges ${ }^{17,18}$. Hyperintense staining on fat-suppressed T1-weighted images, representing dotted foci of hemorrhage, can also be observed ${ }^{19}$. The proximal medial portion of the USL is most commonly affected by endometriosis ${ }^{18}$. According to Bazot et al. ${ }^{17} \mathrm{~T} 2$-weighted thin section oblique axial sequences may improve the ability of conventional MRI to assess USL endometriosis. The left uterosacral endometriosis may be more difficult to diagnose than the right, due to the frequent location of the rectosigmoid colon in the left side of the pelvic cavity ${ }^{17}$.

In a recently published meta-analysis, the sensitivity and specificity of MRI for the diagnosis of USL endometriosis were $85 \%$ and $80 \%{ }^{16}$. In our study we found a sensitivity of $70.3 \%$ and a specificity of $70.5 \%$ for USL endometriosis on MRI.

In patients undergoing surgery, it is particularly relevant to determine whether USL endometriosis is unilateral or bilateral. The risk of urinary dysfunction and dysuria is significantly higher in patients after bilateral USL resection compared to unilateral LUS resection ${ }^{20}$.

MRI technique is useful for detection of the infiltration of the muscle layer of the bowel with a sensitivity of $100 \%$ and a specificity of $75 \%$. On the other hand, it has a limited value in diagnosing the infiltration of the mucosa, because of the thickening of the mucosa caused by edema without infiltration of endometriosis. However, extensive irregularities of the mucosal layer may raise the suspicion of mucosal involvement ${ }^{14,23}$.

In a recently published meta-analysis, the sensitivity and specificity of MRI for the diagnosis of rectosigmoid colon endometriosis were $83 \%$ and $88 \%{ }^{14,16}$. However, our study revealed a sensitivity of $77.8 \%$ and a specificity of $96.8 \%$ for the diagnosis of the endome- triotic lesions of the rectum and a sensitivity of $55.6 \%$ and respectively a specificity of $96.2 \%$ for the diagnosis of endometriotic sigmoid nodules.

Furthermore, according to the specialty literature, in the case of parametrial involvement in endometriosis, MRI showed an accuracy of $96.4 \%{ }^{24}$. On the other hand, our study showed a sensitivity for the MRI technique of only $37.3 \%$ and respectively a specificity of $87.1 \%$ for the parametrial lesions, which is less than what M. Bazot et al. ${ }^{24}$ state in their study published in 2012.

Another aspect assessed by our study was the sensitivity and specificity of the MRI technique for endometriotic bladder invasion. Although the data found in the specialty literature support a higher sensitivity for MRI versus the intraoperative appearance (91\% versus $82 \%)$ and a specificity of only $59 \%$ for the MRI technique versus $65 \%$ for the intraoperative appearance ${ }^{25}$, our data showed a sensitivity of $66.7 \%$ and a specificity of $100 \%$ for the diagnosis of endometriotic invasion of the bladder with the MRI.

\section{CONCLUSIONS}

Endometriosis is a chronic gynecological condition that affects women during their reproductive life. The diagnosis of endometriosis should consider clinical symptoms, physical examination, laboratory tests and various imaging techniques. Ideally, surgery for endometriosis is planned on a careful preoperative investigation. From this point of view, the role of MRI technique to help the diagnose and plan the surgical strategy is essential in the management of the disease. Preoperative findings of all endometriotic lesions is recommended to choose the surgical approach and to plan a multidisciplinary team work ${ }^{21}$.

MRI can be recommended as the ideal imaging technique for mapping endometriotic lesions preoperative, as according to the results of our study, it demonstrated a specificity of at least $70.5 \%$ for endometriotic lesions.

Compliance with ethics requirements: The authors declare no conflict of interest regarding this article. The authors declare that all the procedures and experiments of this study respect the ethical standards in the Helsinki Declaration of 1975, as revised in 2008(5), as well as the national law. Informed consent was obtained from all the patients included in the study. 


\section{References}

1. Camran Nezhat, Farr Nezhat, Ceana Nezha. Endometriosis: ancient disease, ancient treatments. Fertility and Sterility. 2012; 98(6): S1-S62.

2. Serdar E Bulun, Bahar D Yilmaz, Christia Sison, Kaoru Miyazaki, Lia Bernardi, Shimeng Liu, Amanda Kohlmeier, Ping Yin, Magdy Milad, and JianJun Wei. Endometriosis. Endocr. Rev. 2019; 40(4): 1048-1079.

3. Bulun SE. Endometriosis. N Engl J Med. 2009; 360(3): 268-279.

4. Vercellini P, Viganò P, Somigliana E, Fedele L. Endometriosis: pathogenesis and treatment. Nat Rev Endocrinol. 2014; 10(5): $261-275$.

5. Giudice LC. Endometriosis. N Engl J Med. 2010; 362(25): 23892398.

6. Gargett CE, Schwab KE, Deane JA. Endometrial stem/progenitor cells: the first 10 years. Hum Reprod Update. 2016; 22(2): 137163.

7. Brawn J, Morotti M, Zondervan KT, Becker CM, Vincent K. Central changes associated with chronic pelvic pain and endometriosis. Hum Reprod Update. 2014; 20(5): 737-747.

8. Liselotte Mettler, Dietmar Schmidt, Peter Maher. The Impact of Endometriosis on the Health of Women 2016. BioMed Research International, vol. 2016, Article ID 1747280, 1 page, 2016. https:// doi.org/10.1155/2016/1747280.

9. Cynthia Farquhar. Endometriosis. BMJ. 2007; 334(7587): 249253.

10. Dimitra Charatsi, Ourania Koukoura, Irontianta Gkorezi Ntavela, Foteini Chintziou, Georgia Gkorila, Manthos Tsagkoulis, Themistoklis Mikos, George Pistofidis, Jiannis Hajiioannou, Alexandros Daponte. Gastrointestinal and Urinary Tract Endometriosis: A Review on the Commonest Locations of Extrapelvic Endometriosis. Adv Med. 2018; 2018:3461209.

11. Antonio Simone Laganà, Salvatore Giovanni Vitale, Maria Antonietta Trovato, Vittorio Italo Palmara, Agnese Maria Chiara Rapisarda, Roberta Granese, Emanuele Sturlese, Rosanna De Dominici, Stefano Alecci, Francesco Padula, Benito ChiofaIo, Roberta Grasso, Pietro Cignini, Paolo D.Amico, Onofrio Triolo. Full-Thickness Excision versus Shaving by Laparoscopy for Intestinal Deep Infiltrating Endometriosis: Rationale and Potential Treatment Options. Biomed Res Int. 2016; 2016: 3617179.

12. Hudelist G, English J, Thomas AE, Tinelli A, Singer CF, Keckstein J. Diagnostic accuracy of transvaginal ultrasound for non-invasive diagnosis of bowel endometriosis: systematic review and meta-analysis. Ultrasound Obstet Gynecol. 2011;37(3):257-63.

13. Albert L Hsu, Izabella Khachikyan, and Pamela Stratton. Invasive and non-invasive methods for the diagnosis of endometriosis. Clin. Obstet. Gynecol. 2010; 53(2): 413-419.

14. Pietro Valerio Foti, Renato Farina, Stefano Palmucci, Ilenia Anna Agata Vizzini, Norma Libertini, Maria Coronella, Saveria Spadola, Rosario Caltabiano, Marco Iraci, Antonio Basile, Pietro Milone, Antonio Cianci, Giovanni Carlo Ettorre. Endometriosis: clinical features, MR imaging findings and pathologic correlation. Isights Imaging. 2018; 9(2): 149-172.
15. Bis KG, Vrachliotis TG, Agrawal R, Shetty AN, Maximovich $A$, Hricak H. Pelvic endometriosis: MR imaging spectrum with laparoscopic correlation and diagnostic pitfalls. Radiographics. 1997;17(3):639-655.

16. Medeiros LR, Rosa MI, Silva BR, et al. Accuracy of magnetic resonance in deeply infiltrating endometriosis: a systematic review and meta-analysis. Arch Gynecol Obstet. 2015;291(3): 611-621.

17. Bazot M, Gasner A, Ballester M, Daraï E. Value of thin-section oblique axial T2-weighted magnetic resonance images to assess uterosacral ligament endometriosis. Hum Reprod. 2011; 26(2):346-353.

18. Coutinho A, Jr, Bittencourt LK, Pires CE, et al. MR imaging in deep pelvic endometriosis: a pictorial essay. Radiographics. 2011; 31(2): 549-567.

19. Del Frate C, Girometti R, Pittino M, Del Frate G, Bazzocchi M, Zuiani $C$. Deep retroperitoneal pelvic endometriosis: MR imaging appearance with laparoscopic correlation. Radiographics. 2006; 26(6): 1705-1718.

20. Dubernard G, Rouzier R, David-Montefiore E, Bazot M, Darai E. Urinary complications after surgery for posterior deep infiltrating endometriosis are related to the extent of dissection and to uterosacral ligaments resection. J Minim Invasive Gynecol. 2008; 15:235-240.

21. Saavalainen L, Heikinheimo O, Tiitinen A, Härkki P. Deep infiltrating endometriosis affecting the urinary tract-surgical treatment and fertility outcomes in 2004-2013. Gynecol Surg. 2016; 13(4): 435-444.

22. Mehedințu $C$, Brîndușe LA, Brătilă $E$, Monroc $M$, Lemercier $E$, Suaud O, Collet-Savoye C, Roman H. Does computed tomography-based virtual colonoscopy improve the accuracy of preoperative assessment based on Magnetic Resonance Imaging in women managed for colorectal endometriosis? J Minim Invasive Gynecol. 2018;25(6):1009-1017.

23. Busard MP, van der Houwen LE, Bleeker MC, et al. Deep infiltrating endometriosis of the bowel: MR imaging as a method to predict muscular invasion. Abdom Imaging. 2012;37(4):549-557.

24. Marc Bazot, Lamia Jarboui, Marcos Ballester, Cyril Touboul, Isabelle Thomassin-Naggara, Emile Daraï. The value of MRI in assessing parametrial involvement in endometriosis. Human Reproduction. 2012; 27(8): 2352-2358.

25. S. Sillou, S.Poiree, A.E. Millischer, C. Chapron, O. Helenon. Urinary endometriosis: MR Imaging appearance with surgical and histological correlations. Diagnostic and Interventional Imaging. 2015; 96(4): 373-381.

26. Paolo Vercellini, Laura Buggio, Alessandra Borghi, Ermelinda Monti, Umberto gattei, Maria P. Frattaruolo. Medical treatment in the management of deep endometriosis infiltrating the proximal rectum and sigmoid colon: a comprehensive literature review. AOGS. 2018; 97(8): 942-955. 